AUTHOR CORRECTION

\title{
Author Correction: TNF $\alpha$ increases tyrosine hydroxylase expression in human monocytes
}

Adithya Gopinath (D), Martin Badov, Madison Francis, Gerry Shaw, Anthony Collins, Douglas R. Miller (D), Carissa A. Hansen, Phillip Mackie, Malú Gámez Tansey, Abeer Dagra, Irina Madorsky, Adolfo Ramirez-Zamora, Michael S. Okun (D), Wolfgang J. Streit and Habibeh Khoshbouei (D

npj Parkinson's Disease (2021)7:68; https://doi.org/10.1038/s41531-021-00212-8

Correction to: npj Parkinson's Disease https://doi.org/10.1038/ s41531-021-00201-x, published online 20 July 2021

The original version of the published Article had a mistake in the Competing Interests section. The Competing Interests have been updated to the following: Malú Gámez Tansey is a co-inventor on the XPro1595 patent, and is a consultant to and has stock ownership in INmune Bio, which has licensed XPro1595 for neurological indications. The remaining authors declare no competing interests. The HTML and PDF versions of the Article have been corrected.

\begin{abstract}
Open Access This article is licensed under a Creative Commons Attribution 4.0 International License, which permits use, sharing, adaptation, distribution and reproduction in any medium or format, as long as you give appropriate credit to the original author(s) and the source, provide a link to the Creative Commons license, and indicate if changes were made. The images or other third party material in this article are included in the article's Creative Commons license, unless indicated otherwise in a credit line to the material. If material is not included in the article's Creative Commons license and your intended use is not permitted by statutory regulation or exceeds the permitted use, you will need to obtain permission directly from the copyright holder. To view a copy of this license, visit http://creativecommons. org/licenses/by/4.0/.
\end{abstract}

(c) The Author(s) 2021 